\title{
Comparative global gene expression profile of human limbal stromal cells, bone marrow mesenchymal stromal cells, adipose-derived mesenchymal stromal cells and foreskin fibroblasts
}

\author{
Moon Nian Lim ${ }^{1,2^{*}}$, Noor Hamidah Hussin², Ainoon Othman³ ${ }^{3}$ Thiageswari Umapathy ${ }^{4}$, Singh Gurbind ${ }^{5}$, Puteri Baharuddin' ${ }^{1}$ Rahman Jamal ${ }^{6}$ \\ and Zubaidah Zakaria' \\ *Correspondence: moonnianl@gmail.com \\ 'Stem Cell Laboratory, Haematology Unit, Cancer Research Centre, Institute for Medical Research, 50588 Jalan Pahang, \\ Kuala Lumpur, Malaysia. \\ 2Department of Pathology, University Kebangsaan Malaysia Medical Centre, University Kebangsaan Malaysia, Jalan Yaacob Latif, \\ Bandar Tun Razak, 56000 Cheras, Kuala Lumpur, Malaysia. \\ ${ }^{3}$ Faculty of Medicine and Health Sciences, Islamic Science University of Malaysia. \\ ${ }^{4}$ Department of Ophthalmology, Hospital Kuala Lumpur, 50588 Jalan Pahang, Kuala Lumpur, Malaysia. \\ ${ }^{5}$ Stempeutics Research Sdn Bhd, Technology Park Malaysia, 57000 Bukit Jalil, Kuala Lumpur, Malaysia. \\ ${ }^{6}$ UKM Medical Molecular Biology Institute (UMBI), University Kebangsaan Malaysia Medical Centre, University Kebangsaan Malaysia, \\ Jalan Yaacob Latif, Bandar Tun Razak, 56000 Cheras, Kuala Lumpur, Malaysia.
}

\begin{abstract}
Background: Limbal epithelial stem cells (LESC) have great potential in treating the blindness caused by corneal damage. LESC are maintained in stem cell niche called Palisade of Vogt. Limbal stromal (LS) cells are critical component of LESC niche and help in their self renewal. These cells resemble mesenchymal stromal/stem cells with multilineage differentiation potential. However little is known about their gene expression profile compared to MSC derived from various sources.

Methods: In this study, we compared the gene expression profile of LS cells expanded in two different culture conditions: basal media with bFGF, LIF and matrigel (LS-matrigel), as well as basal media with 10\% FBS (LS-FBS). In addition, gene expression profile of LS-FBS cells were compared to bone marrow, adipose-derived MSC and foreskin fibroblasts. Total RNA was extracted from various cell types upon achieving confluency and subjected to microarray experiments (Agilent platform) using Human GE 8 x60k gene chips. Data analysis was done with GeneSpring software.

Results: LS cells cultured in matrigel system showed upregulation of 871 genes as compared to LS-FBS and 58 genes were consistently differentially expressed in LS-FBS as compared to other cell types. Despite many long intergenic non-coding RNA and function unknown genes, differentially expressed genes represent gene ontology for cell signaling molecules including various growth factors, cell metabolism and extracellular matrix components for various biological processes. Samples from the same source were closely clustered by hierachical clustering analysis.

Conclusions: The two culture conditions used in the study affected the gene expression profile of LS cells significantly. The LS cells showed distinct molecular signature as compared to MSC from various other sources. This comparative study will help in understanding the limbal stem cell niche biology and the novel set of genes could be used as biomarkers for LS cells.
\end{abstract}

Keywords: Limbal stromal cells, bone marrow mesenchymal stromal cells, adipose mesenchymal stem cells, gene expression profiling, microarray, limbal epithelial stem cells

\section{Introduction}

Human cornea on the front surface of eye is very critical for vision. The corneal transparency, continuous regeneration and functionality of corneal epithelium play an important role in refraction of light on to the retina. Corneal epithelium is regenerated by unique population of stem cells called limbal epithelial stem cells (LESC) that are located in the basal region of limbus. LESC differ from the corneal epithelium due to the lack of corneo-specific differentiation keratins (K3/K12) expression [1-3], connexin 43-mediated gap junction intercellular communication [4-6], p63 nuclear transcription factor [7,8], cell cycle duration [9], and label retaining property [10]. The limbal stroma provides a unique stem cell niche or microenvironment which is important for the modulation of stemness as it is heavily pigmented, highly innervated and vascularized. Clinically, destruction of LESC or the limbal stromal niche can lead to a pathological stage of LESC deficiency with severe loss of vision [11]. Chronic inflammation in the limbal deficient stroma is sufficient to cause detrimental damage to the conjunctival limbal autograft transplanted to patients or experimental rabbits [12]. These findings suggest that the limbal stromal niche is critical in regulating the selfrenewal and the fate of LESC. Although the mechanism remains elusive, modulation of epithelial proliferation, differentiation, proliferation and apoptosis by the limbal stroma has been 
Lim et al. Stem Cell Biology and Research 2014,

http://www.hoajonline.com/journals/pdf/2054-717X-1-1.pdf

doi: 10.7243/2054-717X-1-1

reported to favor stemness [13]. Limbal stromal (LS) cells are very important component of limbal stromal niche that helps in self renewal of LESC. Recently, LS cells were shown to have multilineage differentiation potential [14-17]. In one of the studies, an ABCG2-expressing FACS sorted side population cells from limbal stroma were able to differentiate into chondrocytes and neurons following differentiation induction [14]. In other studies, multipotent cells were also found in corneal stroma [15] and limbal stroma [16-17]. Earlier, we have reported that an ex vivo expanded LS cells possess multipotent differentiation potential towards adipocytes, osteocytes and chondrocytes [18]. Other stromal cells such as mesenchymal stem/stromal cells (MSC) can also be isolated and expanded in vitro for tissue regeneration applications [19-22]. MSC were first identified from bone marrow aspirates $[23,24]$ and subsequently in Wharton's jelly of human umbilical cords [25], adipose tissue [26], dental tissues $[\mathbf{2 7}, \mathbf{2 8}]$ and skin [29]. Most of the stromal cells derived from various sources expressed the markers of MSCs such as CD44, CD73, CD90, CD105, STRO1 and do not express markers of hematopoietic lineage such as CD14, CD34, CD45 and HLA-DR [30].

The advent of microarray technology has enabled the monitoring of individual and global gene expression patterns across multiple cell populations. Numerous stu-dies have now examined the global gene expression profile of MSC derived from different tissues that exhibit varying levels of proliferation, secretome and differentiation potentials. These studies showed that stromal cells isolated from different sources have unique molecular signatures despite sharing some common genes belonging to MSC when compared to mature fibroblasts [31-33]. It was also shown that gene expression profile of MSC remained stable during ex vivo expansion and subculture and was proven more sensitive to define MSC [34]. Other studies have reported gene expression profile of LESC [35-38], but comparative gene expression analysis of LS cells that are critical component of limbal stem cell niche and help in maintaining self renewal of LESC has not been well studied. As far as genome-wide differential gene expression profiling of LS cells is concerned, there is only one report where analysis were performed on mesenchymal cells derived from limbal explants culture [39]. Gene expression profile of LS cells also has not been compared with other stromal cells such as adipose stromal cells and foreskin fibroblast.

In order to find out the specific molecular signature, cellular function and potential biomarkers of the LS cells, we compared the global gene expression profile including long non-coding RNA (lincRNA) of the expanded LS cells with the MSCs derived from bone marrow, adipose tissue and foreskin fibroblasts. In addition, we also evaluated the effects of two different culture conditions on the LS cells gene expression.

\section{Methods}

The research protocol was approved by the Medical Research and Ethics Committee, Ministry of Health and the Medical Research Secretariat, UKM (University Kebangsaan Malaysia).

\section{Establishment of limbal stromal cell culture}

Corneoscleral rims from three cadaveric donors were obtained from post cornea graft transplantation with informed consent from the donor's relative. The rims were washed with phosphate buffer saline (PBS; Invitrogen Corporation, Carlsbad, CA) and then trimmed to remove the sclera. The limbal tissues were incubated at $37^{\circ} \mathrm{C}$ for $2 \mathrm{~h}$ with dispase (BD Biosciences, Mississauga, Canada) at a concentration of $5 \mathrm{mg} /$ $\mathrm{mL}$. The limbal tissues were then cut into approximately $2 \mathrm{~mm}$ explants after washing with PBS. The limbal explants were cultured on matrigel (BD Biosciences, Mississauga, Canada) coated plates with complete medium containing Dulbecco's Modified Eagle's Medium (DMEM)/F12, 10\% knockout serum replacement, $10 \mu \mathrm{g} / \mathrm{mL}$ insulin, $5 \mu \mathrm{g} / \mathrm{mL}$ transferrin, $5 \mu \mathrm{g} / \mathrm{mL}$ selenium-X, $100 \mathrm{IU} / \mathrm{mL}$ penicillin, $100 \mu \mathrm{g} / \mathrm{mL}$ streptomycin (all from Invitrogen Corporation, Carlsbad, CA, USA), $10 \mathrm{ng} /$ $\mathrm{mL}$ leukemia inhibitory factor (LIF) (Sigma-Aldrich Chemic, Steinheim, Germany) and $4 \mathrm{ng} / \mathrm{mL}$ basic fibroblast growth factor (bFGF; BD Biosciences, Mississauga, Canada) [17]. The expanded limbal stromal cells were subjected to fluorescenceactivated cells sorting (FACS) for the isolation of stage-specific embryonic antigen 4 (SSEA-4+) cells as reported previously [18]. The sorted SSEA-4+ cells were propagated on matrigel coated plate with the medium as mentioned previously. The limbal stromal cells that were maintained in this matrigel system were named as LS-matrigel. On the other hand, some of the sorted cells were maintained on normal plates with Dulbecco's Modified Eagle's Medium (DMEM)/F12 supplemented with $10 \%$ fetal bovine serum (FBS), $100 \mathrm{IU} / \mathrm{mL}$ penicillin, $100 \mu \mathrm{g} /$ $\mathrm{mL}$ streptomycin (all from Invitrogen Corporation, Carlsbad, CA, USA). These cells were identified as LS-FBS.

\section{Human bone marrow mesenchymal stromal/stem cells (BM-MSC) culture}

Bone marrow MSC from three different lots (Millipore, Billerica, MA) were propagated and cultured according to manufacturer's protocol. Briefly, cells at passage 4 were cultured on $0.1 \%$ gelatin coated plates with Mesenchymal Stem Cell Expansion Medium (Millipore, Billerica, MA) supplemented with $8 \mathrm{ng} /$ $\mathrm{mL}$ fibroblast growth factor-2 (FGF-2) (Millipore, Billerica, MA). When the cells were approximately $80 \%$ confluent, they were dissociated with trypsin-EDTA (Invitrogen Corporation, Carlsbad, (A) and passaged or alternatively frozen for later use.

Human adipose-derived mesenchymal stromal/stem cells (AD-MSC) and human foreskin fibroblast cells (HFF) culture

Cryopreserved AD-MSC and HFF $(n=3)$ at early passage (23) were obtained from Stempeutics Research Malaysia and propagated in Dulbecco's Modified Eagle's Medium (DMEM) supplemented with $10 \%$ fetal bovine serum (FBS), $100 \mathrm{IU} / \mathrm{ml}$ 
penicillin and $100 \mu \mathrm{g} / \mathrm{mL}$ streptomycin (all from Invitrogen Corporation, Carlsbad, CA). When the cells were approximately $80 \%$ confluent, they were dissociated with trypsin-EDTA (Invitrogen Corporation, Carlsbad, CA) and passaged or alternatively frozen for later use.

\section{Total RNA extraction and quality assessment}

LS-FBS (S1-P3, S3-P4 and S6-P3), LS-matrigel (S1-P6, S3-P6 and S6-P5), BM-MSC (BM01, BM05 and BM06), AD-MSC (AD001, $A D 002$ and $A D 003$ ) and human foreskin fibroblasts (HFF01, HFF02 and HFF03) at early passage $(<5)$ were harvested with $0.25 \%$ trypsin-EDTA (Invitrogen Corporation, Carlsbad, CA) upon reaching $80-90 \%$ confluency. About $2-3 \times 10^{6}$ cells from each sample were lysed and total RNA was isolated using the RNAeasy kit (Qiagen Hamburg GmbH, Hamburg, Germany) according to the manufacturer's protocol. The extracted RNA was quantified by reading the absorbance at $260 \mathrm{~nm}$, and its purity was evaluated from the $260 / 280$ ratio of absorbance with NanoDrop ${ }^{\mathrm{TM}} 1000$ (Thermo Fisher Scientific Inc). The total RNA integrity was evaluated using the Agilent Bioanalyzer 2100 (Agilent Technologies, Santa Clara, CA).

Gene expression profiling by microarray experiments Genome-wide expression profiles of all the samples were analyzed using Agilent SurePrint G3 8x60K arrays (Agilent Technologies, Santa Clara, CA) that combined both coding and long intergenic non-coding RNA (lincRNA) for human genome. Prior to Cy3 labeling, 2uL of Agilent One-Color Spike Mix dilution was added to 100ng of total RNA for each sample. The total RNA was converted to CDNA and then to Cy3-labeled cRNA using Agilent One-Color RNA Spike-In Kit as per the manufacturer's protocol. The labeled cRNA was purified and quantitated prior to hybridization in hybridization oven at $65^{\circ} \mathrm{C}$ for $17 \mathrm{hr}$.

\section{Microarray image and data analysis}

Microarray image analysis was done using Feature Extraction version 10.7 and data analysis was done by using GeneSpring 11.5 (both from Agilent Technologies, Santa Clara, CA). The threshold was set to intensity value of 1.0. Normalization was done by 75 percentile shift. Baseline transformation was based on the median of samples. The data were further filtered by probeset on flags and expression less than 20. The data has been deposited in Gene Expression Omnibus (GEO) with accession number GSE38947. Unpaired Student's t test was used for statistical analysis. Genes up or downregulated by two-fold change were selected for further analysis. The false discovery rate (FDR) of $5 \%$ was estimated with the BenjaminiHochberg method.

The gene expression profile of LS-FBS and LS-matrigel was compared. LS-FBS were chosen for the subsequent comparisons to other lineages. Hierarchical clustering was performed for LS-FBS versus BM-MSC, AD-MSC and HFF using Pearson Centered and Average-linkage clustering algorithm. Venn diagrams were drawn for the genes upregulated or downregulated in LS-FBS as compared to other lineages. Gene Ontology (GO) analysis was carried out for the upregulated genes and downregulated genes. Significant pathway analysis was also performed wherever possible. Gene functional classification was further carried out by DAVID software [40].

\section{Real time RT-PCR}

First strand CDNA was synthesized with Transcriptor First Strand cDNA synthesis kit (Roche Applied Science, Nonnenwald, Penzberg, Germany) as per manufacturer's protocol. Then, quantitative real time polymerase chain reaction (RT-PCR) was performed by using a LightCycler instrument (Roche Diagnostics, Nonnenwald, Penzberg, Germany). Primers for the panel of genes used in this study are listed in Table 1. Products of PCR amplification were detected through intercalation of the SYBR green dye from LightCycler FastStart DNA Master SYBR Green 1 kit (Roche Diagnostics, Nonnenwald, Penzberg, Germany). The amplification cycles were as follows: $95^{\circ} \mathrm{C}$ for $10 \mathrm{~min}$, followed by 45 cycles at $95^{\circ} \mathrm{C}$ for 15 $\mathrm{s}, 62^{\circ} \mathrm{C}$ for $5 \mathrm{~s}$ and $72^{\circ} \mathrm{C}$ for $20 \mathrm{~s}$. The concentration of $\mathrm{MgCl}_{2}$ in all cycling reactions was $2.4 \mathrm{mM}$. Gene specific products were confirmed by melting curve analysis. Expression of the genes was normalized with the expression of GAPDH and

Table 1. Human primer sequences used for real time RT-PCR.

\begin{tabular}{lllll}
\hline Gene & Accession No. & Sense primer & Antisense primer & Product Size (bp) \\
\hline $\boldsymbol{G A P D H}$ & NM_002046 & GCCAAGGTCATCCATGACAAC & GTCCACCACCCTGTTGCTGTA & 498 \\
$\boldsymbol{S C I N}$ & NM_033128 & ATGGCTTCGGGAAAGTTTATGT & CATCCACCATATTGTGCTGGG & 117 \\
$\boldsymbol{R} \boldsymbol{R A G D}$ & NM_021244 & CTAGCGGACTACGGAGACG & ATGAGCAGGATTCTCGGCTTC & 122 \\
$\boldsymbol{F A B P 3}$ & NM_004102 & ATGGGGACATTCTCACCCTAAA & GCTGTTGTCTCATCGAACTCCA & 91 \\
$\boldsymbol{T F A P 2 B}$ & NM_003221 & TTCCTCCCAAATCGGTGACTT & CGCCGGTGTTGACAGACAT & 75 \\
$\boldsymbol{G P N M B}$ & NM_001005340 & CTTCTGCTTACATGAGGGAGC & GGCTGGTGAGTCACTGGTC & 164 \\
$\boldsymbol{S F R P 1}$ & NM_003012 & ACGTGGGCTACAAGAAGATGG & CAGCGACACGGGTAGATGG & 184 \\
\hline
\end{tabular}

The table details the primers sequences, their accession number and expected product size after RT-PCR. 
Lim et al. Stem Cell Biology and Research 2014,

http://www.hoajonline.com/journals/pdf/2054-717X-1-1.pdf

doi: $10.7243 / 2054-717 \mathrm{X}-1-1$

the expression ratio was calculated by REST software [41].

\section{Results \\ Cell culture}

The LS cells were established from corneoscleral rim tissues and cultured in two different conditions as mentioned in the methods. Cell outgrowths were observed after a few days of plating and the cells reached confluence in about 2-3 weeks. The LS cells appeared to be fibroblastic, elongated and spindle shape growing pattern (Figure 1A). LS-matrigel cells have more elongated feature compared to LS-FBS (as shown in Supplement figure S1). The LS-matrigel cells could be cultured up to 10 passages or more. The LS cells derived from the samples using both methods were used in the subsequent experiments. The BM-MSC, AD-MSC and HFF showed spindle and fibroblastic morphology when cultured and expanded (Figures 1B-1D).
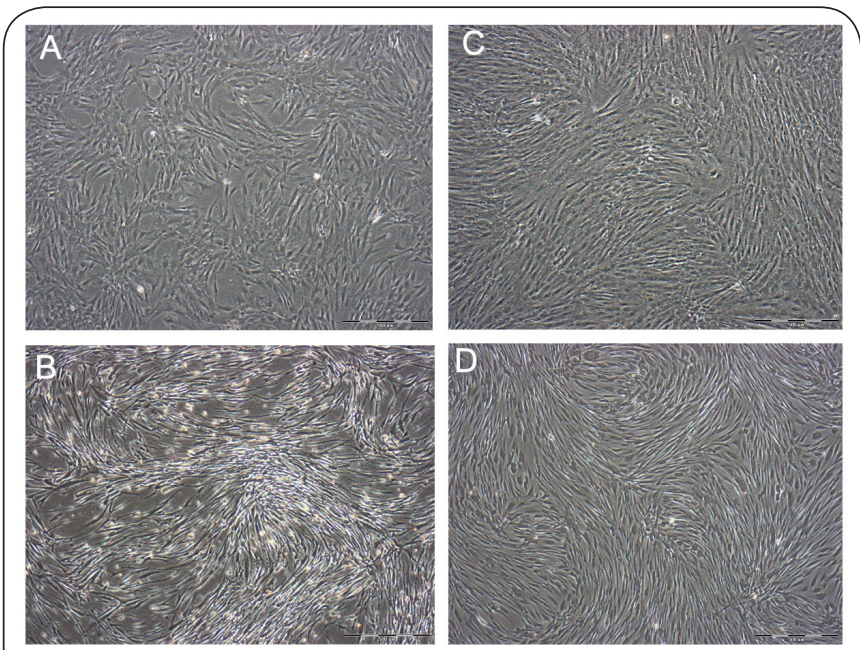

Figure 1. Morphological observations. Phase contrast microscopic image of a confluent culture of (A) Limbal stromal cells, (B) Bone marrow stromal cells, (C) Adipose derived stromal cells and (D) Human foreskin fibroblast. The stromal cells derived from the different sources appeared to be fibroblastic, elongated and spindle shape. Magnification 40x.

\section{Gene expression profiling}

A total of 871 entities were found upregulated in LS-matrigel compared to LS-FBS ( $p<0.05$, fold change $\geq 2$ ). The differentially expressed genes (fold change $>10$ ) of LS-matrigel versus LS FBS are depicted in Table 2. Hierarchical cluster analysis was performed to determine the relationship of the four different cell types (LS-FBS, BM-MSC, AD-MSC and HFF). The dendrogram in Figure 2 demonstrates that MSC isolated from the same source were clustered together. A total of 340 significant differentially expressed genes ( $p<0.05$, fold change $\geq 2$ ) were identified between LS-FBS and BM-MSC. Whereas, 399 and 146 differentially expressed genes were identified for AD-MSC and HFF when compared to LS-FBS respectively. Venn diagram (Figure 3) shows that among the differentially expressed genes, 23 entities were upregulated (including one lincRNA) in LSFBS (Table 3) whereas 35 entities (including of 4 lincRNA) were downregulated in LS cells versus the other three cell types (Table 4). Among these were several genes contributing to the cell signaling receptors such as Frizzled family receptor 5 (FZD5) involved in Wnt signaling, extra cellular matrix proteins (SPON 2), transmembrane glycoprotein (GPMNB) involved in $G$ protein coupled receptor activity and genes related to cell signaling and metabolism such as phosphatidylserine binding (SCIN and SCARB1) or lipid binding proteins (SCIN, $S C A R B I, N P C 2, F A B P 3$, and HS1BP3). In addition, transcription factor involved in sequence specific DNA binding including transcription factor AP-2 beta (TFAP2B) was also upregulated.

However, we found different set of upregulated or downregulated genes when LS-matrigel was compared to the BM-MSC, AD-MSC and HFF. The common upregulated and downregulated genes in LS-matrigel are listed in Appendix $\mathbf{1}$ and 2. Venn diagrams of the comparison are shown in Supplement figures $\mathbf{S 2}$ and $\mathbf{S 3}$. In addition, genes that are differentially expressed when LS-matrigel was compared to BM-MSC, AD-MSC and HFF separately are shown in Appendix 3,4 and 5 respecti-vely. Some of the common genes that upregulated in LS-FBS and LS-matrigel when compared to BM-MSC were insulin-like growth factor binding 5 (IGFBP5), fibrillin 2 (FBN2), proprotein convertase subtilisin/kexin type 9 (PCSK9) and adrenomedullin (ADM). On the other hand, common genes that upregulated in LS-matrigel and LS-FBS when compared to HFF were $\mathrm{Xg}$ blood group $(X g)$, insulin-like growth factor binding protein 2 (IGFBP2) and laminin alpha 3 (LAMA 3). However, common upregulated genes could not be found in LS-FBS and LS-mat-rigel when compared to AD-MSC.

Further functional classification of genes that were highly expressed (more than 10-15 folds) in LS-FBS was done by using DAVID software. The differentially expressed genes as shown in Table 5 were classified as secreted proteins, signaling protein, extra cellular matrix, cell differentiation, basement membrane and cell adhesion protein. Some of the secreted proteins that were highly expressed when compared to BMMSC and AD-MSC were EGF-like-domain, multiple 6 (EGFL6), angiopoietin-like 7 (ANGPTL7), insulin-like growth factor binding protein 2 (IGFBP2) and insulin-like growth factor binding 5 (IGFBP5). These proteins might play important role in proliferation and self renewal of LESC in paracrine fashion in the stem cell niche. Most of the Hox gene family members were downregulated as they are involved in differentiation. This also shows that LS-cells maintain multipotent phenotype by suppressing Hox genes.

For LS-FBS versus BM-MSC, significant pathway analysis $(p<0.05)$ showed that the genes involved in several pathways such as IL-2 (STAT5A, BCL2, PLCB4) and IL-7 (IL-7R and STAT5A), tnfr 2 signaling (MAP3K1), angiotensin II mediated activation of JNK pathway via pyk2 dependent signaling (MAP3K1, AGT), 
Lim et al. Stem Cell Biology and Research 2014,

Table 2. Differentially expressed genes in limbal stromal cells cultured in matrigel system versus non-matrigel system supplemented with fetal bovine serum.

\begin{tabular}{|c|c|c|c|}
\hline Gene Symbol & Gene Name/Description & Acc. No. & Fold Change \\
\hline ADAMTS8 & ADAM metallopeptidase with thrombospondin type 1 motif, 8 & NM_007037 & 14.913507 \\
\hline$A D R A 2 A$ & adrenergic, alpha-2A-, receptor & NM_000681 & 47.013718 \\
\hline ANGPTL4 & angiopoietin-like 4 & NM_139314 & 424.33313 \\
\hline ANGPTL7 & angiopoietin-like 7 & NM_021146 & 14.670821 \\
\hline ANK3 & ankyrin 3, node of Ranvier (ankyrin G) & NM_020987 & 14.409806 \\
\hline$A P C D D 1$ & adenomatosis polyposis coli down-regulated 1 & NM_153000 & 11.659266 \\
\hline$A P O D$ & apolipoprotein D & NM_001647 & 12.362466 \\
\hline$A Q P 3$ & aquaporin 3 (Gill blood group) & NM_004925 & 25.748945 \\
\hline ARHGAP28 & Rho GTPase activating protein 28 & NM_001010000 & 11.816478 \\
\hline ASCL2 & achaete-scute complex homolog 2 (Drosophila) & NM_005170 & 11.49502 \\
\hline CACNA2D3 & calcium channel, voltage-dependent, alpha $2 /$ delta subunit 3 & NM_018398 & 12.480957 \\
\hline CFI & complement factor I & NM_000204 & 12.210217 \\
\hline CILP & cartilage intermediate layer protein, nucleotide pyrophosphohydrolase & NM_003613 & 12.177848 \\
\hline CLCA2 & chloride channel accessory 2 & NM_006536 & 26.598017 \\
\hline COL15A1 & collagen, type XV, alpha 1 & NM_001855 & 22.379642 \\
\hline COL21A1 & collagen, type XXI, alpha 1 & NM_030820 & 48.873936 \\
\hline COL3A1 & collagen, type III, alpha 1 & NM_000090 & 17.54856 \\
\hline COL4A6 & collagen, type IV, alpha 6 & NM_033641 & 12.459421 \\
\hline COL5A1 & collagen, type $\mathrm{V}$, alpha 1 & NM_000093 & 10.208904 \\
\hline COMP & cartilage oligomeric matrix protein & NM_000095 & 23.414925 \\
\hline$C P Z$ & carboxypeptidase Z & NM_001014448 & 21.976519 \\
\hline EGFL6 & EGF-like-domain, multiple 6 & NM_001167890 & 73.905075 \\
\hline FAM65B & family with sequence similarity 65 , member $B$ & NM_014722 & 16.607714 \\
\hline FGF18 & fibroblast growth factor 18 & NM_003862 & 15.78104 \\
\hline$F O S B$ & FBJ murine osteosarcoma viral oncogene homolog B & NM_006732 & 13.191734 \\
\hline GABRE & gamma-aminobutyric acid (GABA) A receptor, epsilon & NM_004961 & 11.908827 \\
\hline GADL1 & glutamate decarboxylase-like 1 & NM_207359 & 38.765053 \\
\hline GAP43 & growth associated protein 43 & NM_002045 & 27.63465 \\
\hline$H 19$ & H19, imprinted maternally expressed transcript (non-protein coding) & NR_002196 & 42.17927 \\
\hline$H G F$ & hepatocyte growth factor (hepapoietin A; scatter factor) & NM_001010931 & 13.644942 \\
\hline HTRA3 & HtrA serine peptidase 3 & NM_053044 & 11.428729 \\
\hline IGSF10 & immunoglobulin superfamily, member 10 & NM_178822 & 27.802753 \\
\hline IRF4 & interferon regulatory factor 4 & NM_002460 & 15.386851 \\
\hline LOC100506700 & hypothetical LOC100506700 & XR_110229 & 24.45396 \\
\hline LRRC17 & leucine rich repeat containing 17 & NM_001031692 & 26.013319 \\
\hline
\end{tabular}


Lim et al. Stem Cell Biology and Research 2014,

http://www.hoajonline.com/journals/pdf/2054-717X-1-1.pdf

doi: 10.7243/2054-717X-1-1

Continuation of Table 2.

\begin{tabular}{|c|c|c|c|}
\hline Gene Symbol & Gene Name/Description & Acc. No. & Fold Change \\
\hline LRRC17 & leucine rich repeat containing 17 & NM_005824 & 23.40266 \\
\hline LSP1 & lymphocyte-specific protein 1 & NM_001013254 & 80.217 \\
\hline MFAP4 & microfibrillar-associated protein 4 & NM_002404 & 10.018822 \\
\hline MGP & matrix Gla protein & NM_000900 & 33.745953 \\
\hline MIAT & myocardial infarction associated transcript (non-protein coding) & NR_003491 & 23.861937 \\
\hline MMP27 & matrix metallopeptidase 27 & NM_022122 & 35.801075 \\
\hline$N / A$ & lincRNA:chr22:27053483-27072438 forward strand & N/A & 31.898119 \\
\hline$N / A$ & lincRNA:chr17:67547498-67549996 forward strand & N/A & 23.818346 \\
\hline$N / A$ & lincRNA:chr12:46826133-46974783 forward strand & N/A & 23.46723 \\
\hline$N / A$ & lincRNA:chr22:27065125-27066565 forward strand & N/A & 13.99885 \\
\hline$N / A$ & lincRNA:chr2:74193717-74210392 reverse strand & $\mathrm{N} / \mathrm{A}$ & 11.909513 \\
\hline$N / A$ & lincRNA:chr2:179803305-179829380 reverse strand & N/A & 10.683858 \\
\hline$N / A$ & lincRNA:chr22:27066072-27067126 forward strand & N/A & 10.115315 \\
\hline NDNF & neuron-derived neurotrophic factor & NM_024574 & 10.847972 \\
\hline OGN & osteoglycin & NM_033014 & 158.96016 \\
\hline$O M D$ & osteomodulin & NM_005014 & 20.503307 \\
\hline OSR2 & odd-skipped related 2 (Drosophila) & NM_053001 & 10.601532 \\
\hline PCOLCE2 & procollagen C-endopeptidase enhancer 2 & NM_013363 & 12.823184 \\
\hline PDGFD & platelet derived growth factor $\mathrm{D}$ & NM_025208 & 41.041542 \\
\hline PDK4 & pyruvate dehydrogenase kinase, isozyme 4 & NM_002612 & 13.998885 \\
\hline$P G A 3$ & pepsinogen 3 , group I (pepsinogen A) & NM_001079807 & 34.137875 \\
\hline RARRES1 & retinoic acid receptor responder (tazarotene induced) 1 & NM_002888 & 19.60683 \\
\hline RASSF2 & Ras association (RalGDS/AF-6) domain family member 2 & NM_014737 & 12.719816 \\
\hline SORCS2 & sortilin-related VPS10 domain containing receptor 2 & NM_020777 & 16.55429 \\
\hline STRA6 & stimulated by retinoic acid gene 6 homolog (mouse) & NM_001199042 & 13.068887 \\
\hline TDRD6 & tudor domain containing 6 & NM_001010870 & 12.645858 \\
\hline THBS4 & thrombospondin 4 & NM_003248 & 42.90762 \\
\hline TMEM26 & transmembrane protein 26 & NM_178505 & 22.539011 \\
\hline TRIL & TLR4 interactor with leucine-rich repeats & NM_014817 & 29.37157 \\
\hline TXNIP & thioredoxin interacting protein & NM_006472 & 17.168047 \\
\hline WNT2 & wingless-type MMTV integration site family member 2 & NM_003391 & 49.876865 \\
\hline$N / A$ & PREDICTED: Homo sapiens hypothetical LOC729420 (LOC729420), miscRNA [XR_110129] & XR_110129 & 10.492821 \\
\hline$N / A$ & $\begin{array}{l}\text { MGC13nov.3.1.L1.1.G04.F.1 NIH_MGC_331 Homo sapiens cDNA clone } \\
\text { MGC13nov.3.1.L1.1.G04, mRNA sequence [EG328730] }\end{array}$ & EG328730 & 10.060941 \\
\hline N/A & PREDICTED: Homo sapiens FLJ46836 protein (FLJ46836), miscRNA [XR_108962] & XR_108962 & 10.016423 \\
\hline
\end{tabular}

Fold change $>10$. 
Lim et al. Stem Cell Biology and Research 2014,
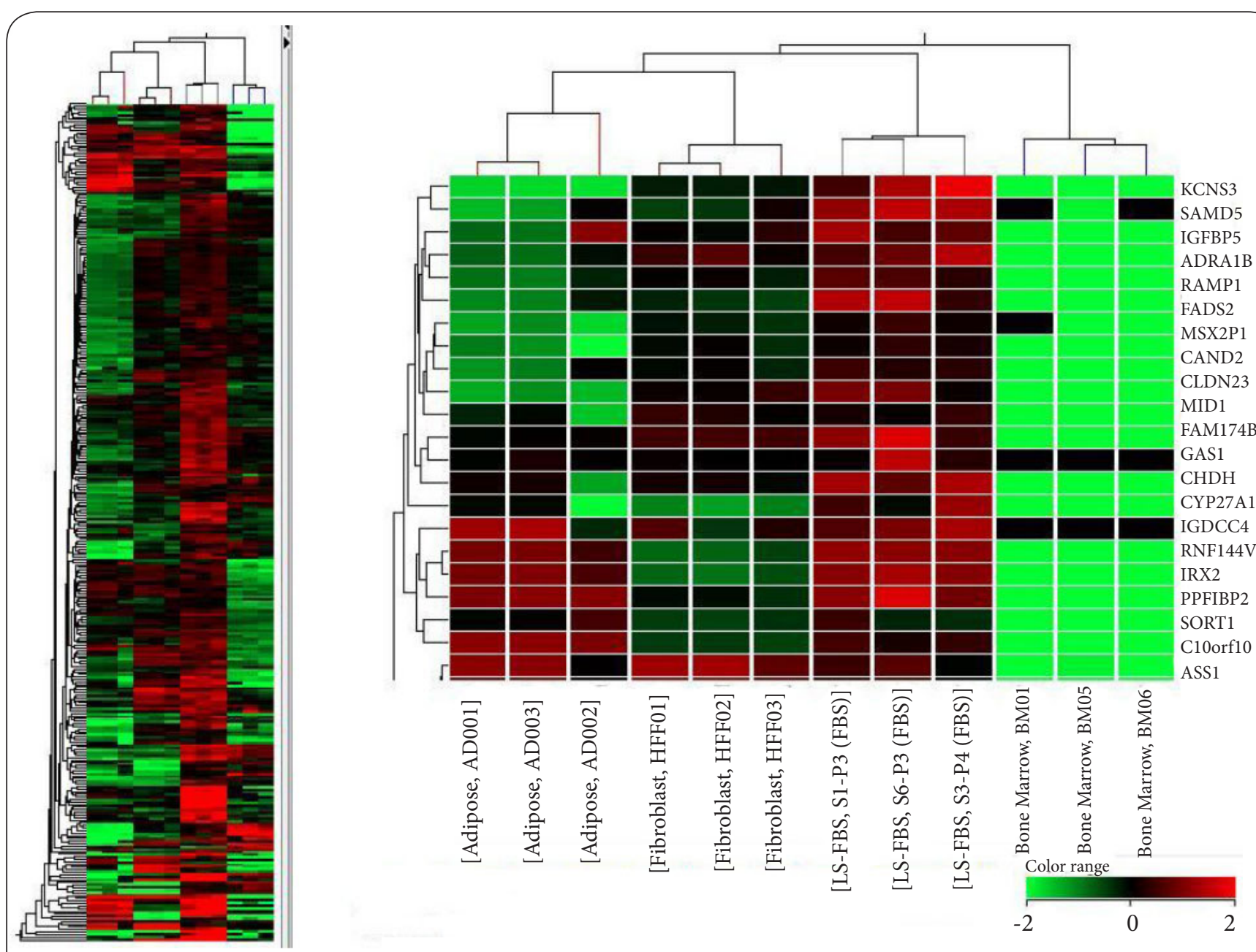

Figure 2. Hierarchical clustering of all the samples from different sources. Dendrogram showing samples isolated from the same sources (limbal stromal cells cultured in fetal bovine serum, LS-FBS; bone marrow mesenchymal stromal/stem cells, BM-MSC; adipose-derived mesenchymal stromal/stem cells, AD-MSC and human foreskin fibroblasts, HFF) were clustered together by upregulated genes in limbal stromal cells. LS-FBS have different molecular signature when compared to other MSC as shown by the hierarchical tree (left panel). The left panel shows the whole hierarchical tree and the right panel shows zoom in on a set of significantly upregulated genes.

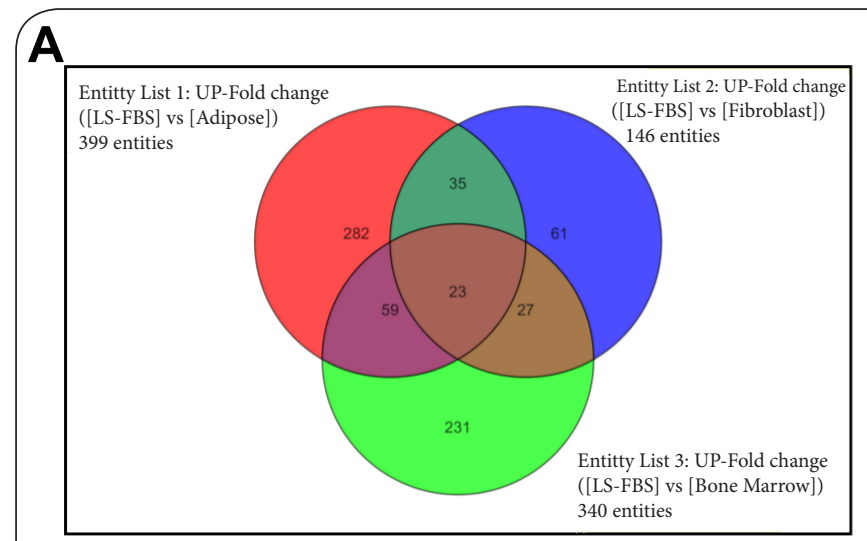

B

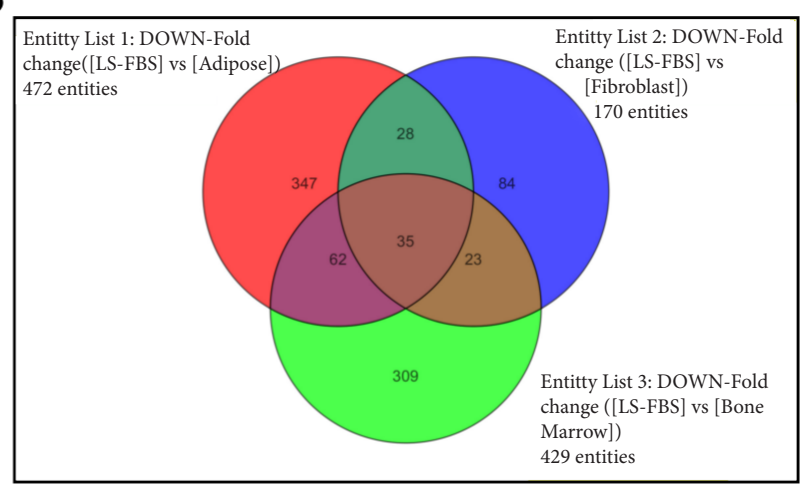

Figure 3. Venn diagrams showing the numbers of all up- (panel A) or downregulated genes (panel B) of LS-FBS when compared to BM-MSC (bone marrow mesenchymal stem cells), AD-MSC (adipose-derived mesenchymal stem cells) and HFF (human foreskin fibroblasts). All gene expressions are $\geq 2$ fold change, $p<0.05$. The common up- or downregulated differentially expressed genes are listed in (Tables 3 and $\mathbf{4})$. 
Lim et al. Stem Cell Biology and Research 2014,

http://www.hoajonline.com/journals/pdf/2054-717X-1-1.pdf

Table 3. List of common upregulated genes in LS-FBS versus BM-MSC, AD-MSC and HFF.

\begin{tabular}{|c|c|c|c|c|c|}
\hline Gene Symbol & Gene Name/Description & Acc. No. & BM-MSC (f.c.) & AD-MSC (f.c.) & HFF (f.c.) \\
\hline SCIN & scinderin & NM_033128 & 330.80643 & 416.52576 & 369.1616 \\
\hline RRAGD & Ras-related GTP binding D & NM_021244 & 218.22987 & 18.668407 & 178.51025 \\
\hline FABP3 & fatty acid binding protein 3 , muscle and heart & NM_004102 & 123.3219 & 155.64526 & 76.11089 \\
\hline TFAP2B & transcription factor AP-2 beta & NM_003221 & 43.46775 & 31.220913 & 35.57746 \\
\hline$G P N M B$ & glycoprotein (transmembrane) $\mathrm{nmb}$ & NM_001005340 & 26.490465 & 12.710969 & 11.586283 \\
\hline NAP1L2 & nucleosome assembly protein 1-like 2 & NM_021963 & 9.873706 & 18.588165 & 9.587671 \\
\hline$O G D H L$ & oxoglutarate dehydrogenase-like & NM_018245 & 10.780043 & 14.660217 & 9.35376 \\
\hline GPNMB & glycoprotein (transmembrane) $\mathrm{nmb}$ & BC011595 & 7.3409696 & 8.595104 & 6.69056 \\
\hline FZD5 & frizzled family receptor 5 & NM_003468 & 8.075183 & 6.3447533 & 6.686808 \\
\hline RENBP & renin binding protein & NM_002910 & 4.8013253 & 4.9874763 & 6.3223376 \\
\hline DNAH5 & dynein, axonemal, heavy chain 5 & NM_001369 & 6.636916 & 6.3912625 & 5.8422527 \\
\hline SPON2 & spondin 2, extracellular matrix protein & NM_012445 & 59.94457 & 12.877473 & 5.7284737 \\
\hline UAP1L1 & UDP-N-acteylglucosamine pyrophosphorylase 1 -like 1 & NM_207309 & 4.6691117 & 7.7450266 & 4.8722553 \\
\hline C6orf155 & chromosome 6 open reading frame 155 & NR_026807 & 5.532519 & 5.84893 & 4.606592 \\
\hline TSPAN10 & tetraspanin 10 & NM_031945 & 18.728783 & 14.794658 & 4.4555798 \\
\hline SH3RF2 & SH3 domain containing ring finger 2 & NM_152550 & 2.2531955 & 4.0488048 & 3.829434 \\
\hline NPC2 & Niemann-Pick disease, type C2 & NM_006432 & 2.3174524 & 4.9840603 & 3.48242 \\
\hline ARSE & arylsulfatase E (chondrodysplasia punctata 1) & AK223183 & 15.381536 & 16.5452 & 3.47192 \\
\hline$S C A R B 1$ & scavenger receptor class $B$, member 1 & NM_005505 & 3.3584666 & 7.5342646 & 2.8759322 \\
\hline C17orf55 & chromosome 17 open reading frame 55 & NR_038080 & 2.2982838 & 2.7519205 & 2.544845 \\
\hline N/A & lincRNA:chr3:142845360-142851335 reverse strand & N/A & 2.506281 & 2.3448408 & 2.4984725 \\
\hline HS1BP3 & HCLS1 binding protein 3 & NM_022460 & 2.2680733 & 4.639097 & 2.460958 \\
\hline FLVCR1 & feline leukemia virus subgroup C cellular receptor 1 & NM_014053 & 2.2281523 & 5.496619 & 2.2000937 \\
\hline
\end{tabular}

f.c=fold change; $N / A=$ not available.

activation of PKC through G-protein coupled receptors (PLCB4) and FAS signaling pathway (BCL2, MAP3K1) were over expressed.

\section{Confirmation of differential expression by RT-PCR analysis}

Differential expression of six regulated genes and a housekeeping gene, GAPDH was determined by RT-PCR as presented in Figure 4. RT-PCR confirmed the differential expression as observed in four cell the types. Specific amplification was confirmed by melting curve analysis. The tendency of differential expression in LS-FBS versus the rest was consistent between microarray data and real-time RT-PCR data in all the genes tested.

\section{Discussion}

In this study, we compared the gene expression of stromal cells derived from different sources namely limbal stromal cells (LS-FBS and LS-matrigel), bone marrow mesenchymal stem cells (BM-MSC), adipose-derived mesenchymal stem cells (ADMSC) and human foreskin fibroblasts (HFF). Morphologically, these cells resembled the fibroblasts with a slight difference in their size and shape. The MSCs derived from various sources are known for their multipotential differentiation towards adipocytes, osteocytes and chondrocytes [42-44]. However, they differ in terms of growth factor, cytokine secretion and immunomodulatory properties [45].

The LS-FBS and LS-matrigel have different molecular sign- 
Lim et al. Stem Cell Biology and Research 2014,

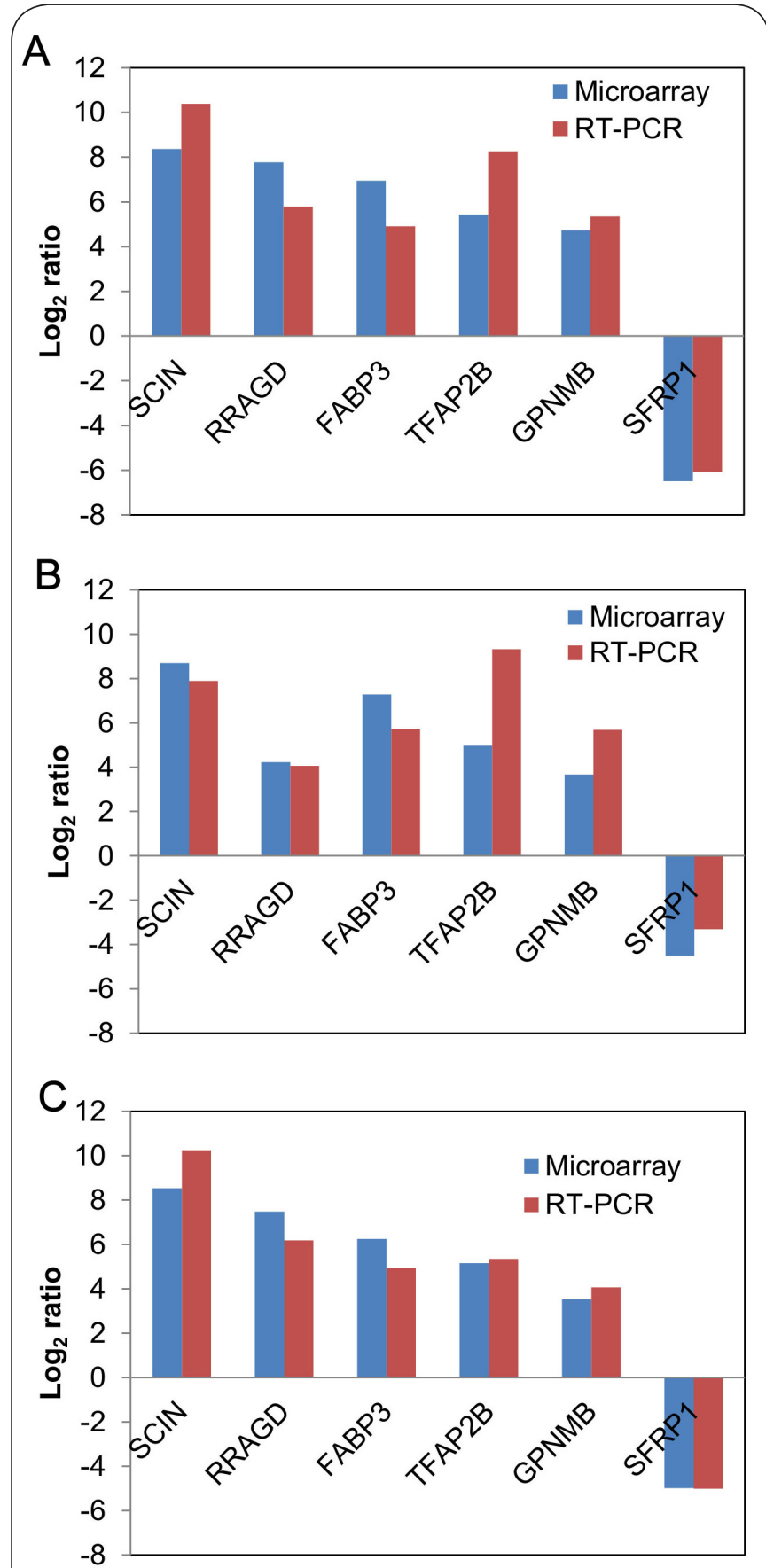

Figure 4. Validation of the expression of genes by relative real time PCR. The bar charts show the mean expression $(n=3$, $\mathrm{p}<0.05$ ) of the selected up- or downregulated genes for each group (A: LS-FBS versus BM-MSC; $\mathbf{B}$ : LS-FBS versus ADMSC; C: LS-FBS versus HFF) are consistent when analyzed by microarray and relative real time PCR. For relative real time PCR, expression of genes was normalized with GAPDH.

atures despite sharing some common genes that are highly expressed compared to other MSC as shown in Tables $\mathbf{2}$ and $\mathbf{5}$ and Appendix 3,4 and 5. Most of the differentially expressed genes in LS-matrigel are involved in the extracellular components such as collagen, type XXI, alpha 1 (COL21A1), matrix metallopeptidase 27 (MMP27), cartilage oligomeric matrix protein (COMP), collagen, type XV, alpha 1 (COL15A1), collagen, type III, alpha 1 (COL3A1), collagen type IV, alpha 6 (COL4A6) and collagen type $\mathrm{V}$, alpha 1 (COL5A1). The results demonstrated that when LS cells were cultured with FBS without matrigel, the expression of these matrix proteins was downregulated. The matrigel provided an efficient culture microenvironment supporting the production of ECM. Our findings concurred with others that culturing method can have influence on the gene expression profile of stem cells [46]. Higher expression of ECM proteins in LS-matrigel as compared to LS-FBS might mimic the stem cell niche environment for LS cells and might be useful in the maintenance of the limbal epithelial stem cells. Different culture conditions have effect on cell characteristic and gene expression. We believe this maybe an adaptive response to stimuli during damage or pathogenesis of limbal epithelial stem cell niche. Due to this adaptive response, LS cells may generate necessary paracrine factors and ECM proteins to help in recovery process. In addition, LIF has been reported to play a role in self renewal and differentiation of human and mouse stem cells [47]. Murine embryonic stem cells for instance depend strictly on LIF for self renewal and maintenance of pluripotency but LIF is not able to maintain human embryonic stem cells. However, our result showed that both LIF and matrigel were not able to induce pluripotency of the SSEA-4+ LS cells.

Although cell culture conditions, growth factors and even FBS affect the gene expression of the cultured cells, there is still no standard culture protocol for MSC derived from various sources. The characteristics of MSC are always confirmed by immunophenotyping and differentiation assay towards adipocytes, osteocytes and chondrocytes [30]. However, the ex vivo expanded MSC are normally heterogenous. Therefore, a systematic ex vivo global molecular characterization of MSC is needed in the future to define MSC. Thus, gene expression profiling provides an important tool for comparison and characterization of stromal cells from various sources.

In this study, LS-FBS and LS-matrigel were compared to BMMSC, AD-MSC and HFF cultured in FBS. This study demonstrates a set of novel differentially expressed genes in LS-FBS compared to BM-MSC, AD-MSC and HFF. We also found different set of common genes that were highly expressed by LS-matrigel compared to BM-MSC, AD-MSC and HFF cultured in FBS. This might be due to the culture media components such as LIF, bFGF and matrigel. For LS-FBS, the highest expressed gene, $\mathrm{SCIN}$ is a $\mathrm{Ca}^{2+}$-dependent actin severing and capping protein [48] which is presumed to regulate exocytosis by affecting the organization of the microfilament network underneath the plasma membrane. This may play an important role in secretion of various growth factors required for maintenance and self renewal of LESC. It also regulates chondrocytes proliferation and differentiation. The second highly expressed 
Lim et al. Stem Cell Biology and Research 2014,

http://www.hoajonline.com/journals/pdf/2054-717X-1-1.pdf

doi: $10.7243 / 2054-717 \mathrm{X}-1-1$

Table 4. List of common downregulated genes in LS-FBS versus BM-MSC, AD-MSC and HFF.

\begin{tabular}{|c|c|c|c|c|c|}
\hline Gene Symbol & Gene Name/Description & Acc. No. & BM-MSC (f.c.) & AD-MSC (f.c.) & HFF (f.c.) \\
\hline HOXA11AS & HOXA11 antisense RNA (non-protein coding) & NR_002795 & -104.227234 & -166.47116 & -673.34393 \\
\hline HOXA10 & homeobox A10 & NM_018951 & -123.810524 & -181.91698 & -324.92493 \\
\hline HOXA11 & homeobox A11 & NM_005523 & -36.106262 & -44.978073 & -264.6142 \\
\hline HOXА9 & homeobox A9 & NM_152739 & -643.6674 & -382.13437 & -190.41304 \\
\hline lincRNA & lincRNA:chr12:54356229-54357908 & n.a & -13.816334 & -23.520226 & -106.52508 \\
\hline LOC442249 & similar to keratin 18 & XR_019231 & -39.17349 & -40.84192 & -47.219604 \\
\hline HOXA7 & homeobox A7 & NM_006896 & -473.85187 & -266.04224 & -45.93801 \\
\hline HOXC10 & homeobox C10 & NM_017409 & -41.060524 & -73.95265 & -41.661804 \\
\hline SFRP1 & secreted frizzled-related protein 1 & NM_003012 & -90.09236 & -22.70849 & -31.701826 \\
\hline lincRNA & lincRNA:chr12:54356229-54357908 reverse strand & n.a & -4.4482675 & -6.152943 & -26.052305 \\
\hline EBF3 & early B-cell factor 3 & NM_001005463 & -111.54111 & -54.667686 & -25.794918 \\
\hline MEIS1 & Meis homeobox 1 & NM_002398 & -9.061138 & -7.985613 & -23.654848 \\
\hline HOXD8 & homeobox D8 & NM_019558 & -53.95993 & -83.73045 & -18.824736 \\
\hline HCLS1 & hematopoietic cell-specific Lyn substrate 1 & NM_005335 & -5.432739 & -9.804886 & -16.318146 \\
\hline HAND2 & heart and neural crest derivatives expressed 2 & NM_021973 & -21.603893 & -57.825478 & -14.021899 \\
\hline$I L 17 B$ & interleukin 17B & NM_014443 & -15.500265 & -9.498544 & -10.416743 \\
\hline TMEM90В & transmembrane protein 90B & NM_024893 & -195.35493 & -142.35834 & -7.5122113 \\
\hline FRMPD4 & FERM and PDZ domain containing 4 & NM_014728 & -9.06647 & -13.105078 & -6.804531 \\
\hline $\mathrm{CDH} 2$ & cadherin 2 , type $1, \mathrm{~N}$-cadherin (neuronal) & NM_001792 & -13.568187 & -16.845877 & -5.71267 \\
\hline lincRNA & lincRNA:chr2:177494316-177502754 reverse strand & n.a & -11.785658 & -9.501191 & -5.4580956 \\
\hline lincRNA & lincRNA:chr2:177494316-177502302 reverse strand & n.a & -11.574628 & -9.275996 & -5.1087427 \\
\hline MYCBP & c-myc binding protein & NM_012333 & -4.902564 & -3.403298 & -4.6458 \\
\hline GATA6 & GATA binding protein 6 & NM_005257 & -14.644289 & -8.480716 & -4.317858 \\
\hline SLC35E2 & solute carrier family 35 , member E2 & NM_182838 & -2.3155887 & -3.433437 & -4.1792254 \\
\hline SEMA7A & semaphorin 7A, GPI membrane anchor & NM_003612 & -10.770672 & -4.537565 & -3.8937697 \\
\hline NCKAP5 & NCK-associated protein 5 & NM_207363 & -7.6027536 & -2.4458163 & -3.5850215 \\
\hline$N R 2 F 2$ & nuclear receptor subfamily 2 , group F, member 2 & NM_021005 & -2.2446127 & -2.1425328 & -3.4852633 \\
\hline TSHZ3 & teashirt zinc finger homeobox 3 & NM_020856 & -3.4907699 & -2.9466493 & -3.434508 \\
\hline MLXIP & MLX interacting protein & NM_014938 & -2.431865 & -3.559918 & -2.3397596 \\
\hline
\end{tabular}

f.c $=$ fold change; $n . a=$ not available.

gene, Ras-related GTP binding $D$ is a monomeric guanine nucleotide-binding protein, or $\mathrm{G}$ protein. The $\mathrm{G}$ proteins act as molecular switches in numerous cell processes and signaling pathways (supplied by OMIM). The intracellular fatty acid binding protein 3 (FABP3) is another highly expressed gene in LS cells. The fatty acid binding proteins (FABP) belong to a multigene family. FABP are thought to participate in the uptake, intracellular metabolism and/or transport of longchain fatty acids. They might be responsible in regulating cell growth and proliferation. One of the FABP genes, FABP4 has been reported to be upregulated during adipogenesis of MSC $[31,49]$. Fourthly, the transcription factor AP-2 beta (TFAP2B) is involved in the regulation of cell proliferation and differentiation during embryonic development. This protein functions both as transcriptional activator and repressor by binding to different promoters. Mutation in TFAP2B gene has been reported in autosomal dominant Char syndrome indicating its function in the differentiation of neural crest cell derivatives. Since cornea is one of the derivative of neural crest during embryo development, the over expression of this gene is significant. In addition, angiopoietin-like 7 (ANGPTL7) was highly expressed in LS cells. The protein acts as a negative regulator of angiogenesis besides playing a role as morphogen in inducing a corneal phenotype in vivo [50]. Another highly expressed gene related to the eye was tetraspanin 10 (TSPAN10) [51] and the function of this protein 
Lim et al. Stem Cell Biology and Research 2014,

Table 5. Differential biological process associated gene expression in LS-FBS as compared to BM-MSC, AD-MSC and HFF.

\begin{tabular}{|c|c|c|}
\hline $\begin{array}{l}\text { Genes Over expressed in LS-FBS vs } \\
\text { BM-MSC ( }>15 \text { fold change) }\end{array}$ & $\begin{array}{l}\text { Genes Over expressed in LS-FBS vs } \\
\text { AD-MSC ( }>10 \text { fold change) }\end{array}$ & $\begin{array}{l}\text { Genes Over expressed in LS-FBS vs HFF } \\
(>10 \text { fold change })\end{array}$ \\
\hline Secreted Protein & Signal Protein & Signal Protein \\
\hline EGF-like-domain, multiple 6 [EGFL6] & 24-dehydrocholesterol reductase [DHCR24] & EGF-like-domain, multiple 6 [EGFL6] \\
\hline MAM domain containing $2[M A M D C 2]$ & Acid phosphatase 5 , tartrate resistant & Xg blood group $[X G]$ \\
\hline Adrenomedullin $[A D M]$ & {$[A C P 5]$} & Deleted in bladder cancer $1[D B C 1]$ \\
\hline Angiopoietin-like 7 [ANGPTL7] & Angiopoietin-like 7 [ANGPTL7] & Glycoprotein (transmembrane) $\mathrm{nmb}$ \\
\hline Angiotensinogen (serpin peptidase inhibitor) & Arylsulfatase $\mathrm{E}$ (chondrodysplasia punctata 1) [ARSE] & {$[G P N M B]$} \\
\hline $\begin{array}{l}{[A G T]} \\
\text { Chromosome } 10 \text { open reading frame } 58\end{array}$ & Bone morphogenetic protein $4[B M P 4]$ & $\begin{array}{l}\text { Insulin-like growth factor binding protein } 2 \text {, } \\
36 \mathrm{kDa}[I G F B P 2]\end{array}$ \\
\hline C10orf58] & Carboxypeptidase A4 [CPA4] & Integrin, alpha $8[I T G A 8]$ \\
\hline Fibrillin $2[F B N 2]$ & $\begin{array}{l}\text { Glycoprotein (transmembrane) i } \\
\text { Henaranase }[H P S E]\end{array}$ & Laminin, alpha 3 [LAMA3] \\
\hline Gremlin 2 [GREM2] & anase $[H P S E]$ & Podoplanin $[P D P N]$ \\
\hline 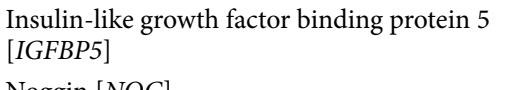 & $\begin{array}{l}\text { Sema domain, immunoglobulin domain (Ig), Short } \\
\text { basic domain, secreted, (semaphorin) 3A [SEMA3A] }\end{array}$ & $\begin{array}{l}\text { Retinoic acid receptor responder (tazarotene } \\
\text { induced) } 2[\text { [RARRES2] }\end{array}$ \\
\hline Noggin $[N O G]$ & Similar to Mast/stem cell growth factor receptor & \\
\hline Podocan $[P O D N]$ & precursor (SCFR) (Proto-oncogene tyrosine-protein & Developmental Protein \\
\hline Proprotein convertase subtilisin/kexin type 9 & kinase Kit) (c-kit) [CD117] & EGF-like-domain, multiple 6[EGFL6] \\
\hline$[$ PCSK9 $]$ & Sodium channel, voltage-gated, type I, beta & Glycoprotein M6B [GPM6B] \\
\hline Retinoic acid receptor responder (tazarotene & {$[S C N 1 B]$} & Integrin, alpha 8 [ITGA8] \\
\hline & Spondin 2, ECM [SPON2] & Podoplanin $[P D P N]$ \\
\hline Extra Cellular Matrix & Transmembrane & Basement Membrane \\
\hline EGF-like-domain, multiple 6 [EGFL6] & 24-dehydrocholesterol reductase [DHCR24] & EGF-like-domain, multiple 6 [EGFL6] \\
\hline MAM domain containing 2 [MAMDC2] & GTPase, IMAP family member 2 [GIMAP2] & Laminin, alpha 3 [LAMA3] \\
\hline Fibrillin $2[F B N 2]$ & $\mathrm{N}$-acetyltransferase 8-like (GCN5-related, putative) & Cell Adhesion Protein \\
\hline Podocan $[P O D N]$ & & EGF-like-domain, multiple 6[EGFL6] \\
\hline & $\begin{array}{l}\text { NADH dehydrogenase (ubiquinone) } 1 \text {, subcomplex } \\
\text { unknown, } 1,6 \mathrm{kDa} \text {; }\end{array}$ & Integrin, alpha 8 [ITGA8] \\
\hline Cell Differentiation & UDP-N-acetyl-alpha-D-galactosamine: polypeptide $\mathrm{N}$ & Lamının, alpha 3 [LAMA3] \\
\hline EGF-like-domain, multiple 6 [EGFL6] & acetylgalactosaminyl transferase 14 [GalNAc-T14] & \\
\hline Forkhead box L2 [FOXL2] & Adrenergic, beta-2-, receptor surface $[A D R B 2]$ & Differentiation \\
\hline Glycoprotein M6B [GPM6B] & Epoxide hydrolase 4 [ EPHX4] & EGF-like-domain, multiple 6 [EGFL6] \\
\hline Integrin, alpha 8 [ITGA8] & Glycoprotein (transmembrane) nmb [GPNMB] & Glycoprotein M6B [GPM6B] \\
\hline Noggin $[N O G]$ & $\begin{array}{l}\text { Potassium inwardly-rectifying channel, subfamily J, } \\
\text { member } 2[K C N J 2]\end{array}$ & Integrin, alpha 8 [ITGA8] \\
\hline \multirow{7}{*}{$\begin{array}{l}\text { Unknown function } \\
\text { lincRNA:chrX:115401722-115413847 reverse } \\
\text { strand }\end{array}$} & Purinergic receptor P2X, ligand-gated ion channel, 7 & Unknown function \\
\hline & $\begin{array}{l}{[P 2 R X 7]} \\
\text { Receptor accessory protein } 2[R E E P 2]\end{array}$ & \multirow[t]{6}{*}{$\begin{array}{l}\text { lincRNA:chr10:134136360-134144210 } \\
\text { forward strand }\end{array}$} \\
\hline & Sodium channel, voltage-gated, type I, beta; & \\
\hline & $\begin{array}{l}\text { solute carrier family } 4 \text {, sodium bicarbonate cotranspor- } \\
\text { ter, member } 8[S L C 4 A 8]\end{array}$ & \\
\hline & $\begin{array}{l}\text { Solute carrier family } 7 \text { (cationic amino acid transporter, } \\
\text { y+ system), member } 2[\text { SLC7A2] }\end{array}$ & \\
\hline & Tetraspanin $10[$ TSPAN10] & \\
\hline & $\begin{array}{l}\text { Transmembrane and tetratricopeptide repeat containing } \\
1[\text { TMTC1] }\end{array}$ & \\
\hline
\end{tabular}

is unknown. The transmembrane glycoprotein (GPNMB) was also reported to be expressed in the lowly metastatic human melanoma cell lines and xenografts and it could add in melanogenesis as the limbus of the human eyes is rich in melanin. Spondin 2 (SPON2) which was also highly expressed in LS cells is a cell adhesion protein that promotes adhesion and outgrowth of hippocampal embryonic neurons while inhibit angiogenesis [52]. The antiangiogenesis properties of this protein might help in maintaining transparency of cornea by inhibiting neoangiogenesis.

Polisetti et al., recently reported a different set of differentially expressed genes in LS cells related to extracellular 
Lim et al. Stem Cell Biology and Research 2014,

http://www.hoajonline.com/journals/pdf/2054-717X-1-1.pdf

doi: 10.7243/2054-717X-1-1

components, cell adhesion molecules (microfibrillar associated protein 5 , syndecan 2 , matrix-remodelling associated 5 , chondroitin sulfate proteoglycan 4 and collagen 8 alpha 1) as compared to BM-MSC [36]. However, by using different approaches such as single color versus dual color hybridization and isolation methods, our results revealed novel genes involved in the biological processes and molecular functions that have not been reported for ex vivo cultured LS cells. Besides extracellular related genes (LAMA3, IGFBP2, IGFBP5) and cell adhesion molecules (SPON2, JAM2, EGFL6, ITGA8), most of the genes significantly overexpressed belonged to the various biological process and molecular functions. In addition, many of the downregulated genes encode the class of transcription factors called homeobox genes that are involved in differentiation (HOXD8, HOXA9, HOXA7, HOXC10, HOXA10, and HOXA11). This shows that the LS cells are multipotent and suppressing the expression of $\mathrm{HOX}$ gene family members. These DNA-binding transcription factors may regulate gene expression, morphogenesis, and differentiation. The HOX genes have been reported to play a role in both the early stem cell function as well as in the later stages of hematopoietic differentiation, and perturbation of HOX genes expression can be leukomogenic [53].

The Wnt pathway has been implicated in the regulation of self-renewal and cell fate determination in embryogenesis and stem cells [54]. Optimal level of $\mathrm{Wnt} / \beta$ catenin signalling increased the proliferation and colony-forming efficiency of primary LESC while maintaining the stem cell phenotype of these cells [55]. This was also shown in Dkk2 knockout mice where they displayed epidermal differentiation on the ocular surface [56]. PAX6 expression was also lost in the corneal epithelial cells of these mice, suggesting it is downstream of $D k k 2$ [56]. Deficiencies in PAX6 leads to aniridia resulting in impaired corneal epithelial function and eventual LESC failure, which may be due to altered niche development. Interestingly, we found high expression of frizzled family receptor 5 (FZD5) in LS-FBS compared to the other stromal cells. High level of Wnt signaling pathway in LS-FBS and LS-matrigel cells (as shown in Table 3 and Appendix 3 ) may help to modulate the proliferation, self-renewal and differentiation of LESC. This demonstrates the importance of limbal niche control over LESC fate during development.

In this study, we also reported a set of unknown genes and long intergenic non-coding RNAs (lincRNAs) which are highly expressed in LS cells (Tables 2 and $\mathbf{5}$ ). LincRNAs have been shown to act in the circuitry controlling self renewal and differentiation of stem cells by epigenetic modifications $[57,58]$. Further studies would be needed to elucidate the functions of these lincRNAs.

\section{Conclusion}

We report a novel set of genes that are consistently highly expressed in LS cells compared to the bone marrow MSC, adipose-derived MSCs and foreskin fibroblasts. The LS cells have unique molecular signature compared to other MSC lineages. Thus, the highly upregulated genes in LS cells could be used as biomarkers by using real time RT-PCR which is less labourious and quicker as compared to microarray analysis. The knowledge gained can help us to improve our understanding of the cellular signaling pathways involved in LESC self-renewal, survival and differentiation, and may aid in the development of strategies to improve the tissue regeneration potential of these cells.

\section{Additional files}

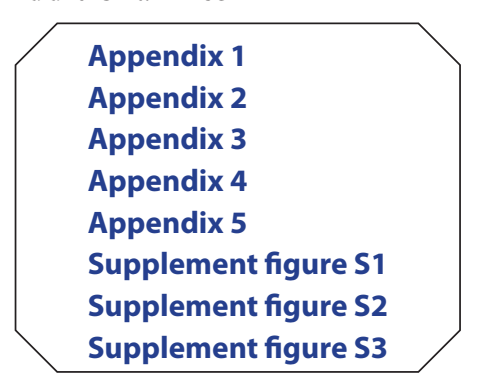

Competing interests

The authors declare that they have no competing interests.

Authors' contributions

\begin{tabular}{|l|c|c|c|c|c|c|c|c|}
\hline Authors' contributions & ML & NH & AO & TU & GS & PB & RJ & ZZ \\
\hline Research concept and design & $\checkmark$ & $\checkmark$ & $\checkmark$ & $\checkmark$ & -- & -- & $\checkmark$ & -- \\
\hline $\begin{array}{l}\text { Collection and/or assembly } \\
\text { of data }\end{array}$ & $\checkmark$ & $\checkmark$ & -- & $\checkmark$ & -- & $\checkmark$ & -- & -- \\
\hline Data analysis and interpretation & $\checkmark$ & $\checkmark$ & -- & $\checkmark$ & $\checkmark$ & -- & -- & -- \\
\hline Writing the article & $\checkmark$ & $\checkmark$ & $\checkmark$ & -- & $\checkmark$ & -- & -- & -- \\
\hline Critical revision of the article & $\checkmark$ & $\checkmark$ & -- & -- & $\checkmark$ & $\checkmark$ & $\checkmark$ & $\checkmark$ \\
\hline Final approval of article & $\checkmark$ & -- & -- & -- & -- & -- & -- & $\checkmark$ \\
\hline Statistical analysis & $\checkmark$ & -- & -- & -- & -- & -- & -- & -- \\
\hline
\end{tabular}

\section{Acknowledgement}

The authors wish to thank the Director General of Health, Malaysia for permission to publish this paper. This study was supported by a Ministry of Health grant, NMRR-09-258-3749/ JPP-IMR: 09-010. We thank the Director of Institute for Medical Research, Dr Shahnaz Murad for her guidance and support.

Publication history

Editor: Kameshwar Prasad Singh, University of Rochester, USA. Received: 22-Oct-2013 Revised: 12-Nov-2013

Accepted: 27-Nov-2013 Published: 06-Jan-2014

\section{References}

1. Schermer A, Galvin S and Sun TT. Differentiation-related expression of a major $64 \mathrm{~K}$ corneal keratin in vivo and in culture suggests limbal location of corneal epithelial stem cells. J Cell Biol. 1986; 103:49-62. Article | PubMed Abstract | PubMed Full Text

2. Chen WY, Mui MM, Kao WW, Liu CY and Tseng SC. Conjunctival epithelial cells do not transdifferentiate in organotypic cultures: expression of K12 keratin is restricted to corneal epithelium. Curr Eye Res. 1994; 13:765-78. | Article | PubMed

3. Liu CY, Zhu G, Converse R, Kao CW, Nakamura H, Tseng SC, Mui MM, Seyer J, Justice MJ, Stech ME and et al. Characterization and chromosomal localization of the cornea-specific murine keratin gene 
Lim et al. Stem Cell Biology and Research 2014,

Krt1.12. J Biol Chem. 1994; 269:24627-36. | Article | PubMed

4. Matic M, Petrov IN, Chen S, Wang C, Dimitrijevich SD and Wolosin JM Stem cells of the corneal epithelium lack connexins and metabolite transfer capacity. Differentiation. 1997; 61:251-60. | Article | PubMed

5. Matic M, Petrov IN, Rosenfeld T and Wolosin JM. Alterations in connexin expression and cell communication in healing corneal epithelium. Invest Ophthalmol Vis Sci. 1997; 38:600-9. | Article | PubMed

6. Wolosin JM, Xiong X, Schutte $M$, Stegman $Z$ and Tieng A. Stem cells and differentiation stages in the limbo-corneal epithelium. Prog Retin Eye Res. 2000; 19:223-55. | Article | PubMed

7. Pellegrini G, Dellambra E, Golisano O, Martinelli E, Fantozzi I, Bondanza $S$, Ponzin D, McKeon F and De Luca M. p63 identifies keratinocyte stem cells. Proc Natl Acad Sci U S A. 2001; 98:3156-61. | Article | PubMed Abstract | PubMed Full Text

8. Lim MN, Umapathy T, Baharuddin PJ and Zubaidah Z. Characterization and safety assessment of bioengineered limbal epithelium. Med $J$ Malaysia. 2011; 66:335-41. | Pdf | PubMed

9. Cotsarelis G, Cheng SZ, Dong G, Sun TT and Lavker RM. Existence of slow-cycling limbal epithelial basal cells that can be preferentially stimulated to proliferate: implications on epithelial stem cells. Cell. 1989; 57:201-9. | Article | PubMed

10. Lehrer MS, Sun TT and Lavker RM. Strategies of epithelial repair: modulation of stem cell and transit amplifying cell proliferation. J Cell Sci. 1998; 111 ( Pt 19):2867-75. | Article | PubMed

11. Puangsricharern V and Tseng SC. Cytologic evidence of corneal diseases with limbal stem cell deficiency. Ophthalmology. 1995; 102:1476-85. | Article | PubMed

12. Tsai RJ and Tseng SC. Effect of stromal inflammation on the outcome of limbal transplantation for corneal surface reconstruction. Cornea. 1995; 14:439-49. | Article | PubMed

13. Espana EM, Kawakita T, Romano A, Di Pascuale M, Smiddy R, Liu CY and Tseng SC. Stromal niche controls the plasticity of limbal and corneal epithelial differentiation in a rabbit model of recombined tissue. Invest Ophthalmol Vis Sci. 2003; 44:5130-5. | Article | PubMed

14. Du Y, Funderburgh ML, Mann MM, SundarRaj N and Funderburgh JL. Multipotent stem cells in human corneal stroma. Stem Cells. 2005; 23:1266-75. | Article | PubMed Abstract | PubMed Full Text

15. Choong PF, Mok PL, Cheong SK and Then KY. Mesenchymal stromal celllike characteristics of corneal keratocytes. Cytotherapy. 2007; 9:252-8. | Article | PubMed

16. Polisetty N, Fatima A, Madhira SL, Sangwan VS and Vemuganti GK. Mesenchymal cells from limbal stroma of human eye. Mol Vis. 2008; 14:431-42. | Article | PubMed Abstract | PubMed Full Text

17. Dravida S, Pal R, Khanna A, Tipnis SP, Ravindran G and Khan F. The transdifferentiation potential of limbal fibroblast-like cells. Brain Res Dev Brain Res. 2005; 160:239-51. | Article | PubMed

18. Lim MN, Hussin NH, Othman A, Umapathy T, Baharuddin P, Jamal R and Zakaria Z. Ex vivo expanded SSEA-4+ human limbal stromal cells are multipotent and do not express other embryonic stem cell markers. Mol Vis. 2012; 18:1289-300. | PubMed Abstract | PubMed Full Text

19. Tolar J, Le Blanc K, Keating A and Blazar BR. Concise review: hitting the right spot with mesenchymal stromal cells. Stem Cells. 2010; 28:144655. | Article | PubMed Abstract | PubMed Full Text

20. Wright KT, El Masri W, Osman A, Chowdhury J and Johnson WE. Concise review: Bone marrow for the treatment of spinal cord injury: mechanisms and clinical applications. Stem Cells. 2011; 29:169-78. | Article | PubMed Abstract | PubMed Full Text

21. Locke $M$, Feisst $V$ and Dunbar PR. Concise review: human adiposederived stem cells: separating promise from clinical need. Stem Cells. 2011; 29:404-11. | Article | PubMed

22. Mizuno H, Tobita M and Uysal AC. Concise review: Adipose-derived stem cells as a novel tool for future regenerative medicine. Stem Cells. 2012; 30:804-10. | Article | PubMed

23. Friedenstein AJ, Piatetzky S, II and Petrakova KV. Osteogenesis in transplants of bone marrow cells. J Embryol Exp Morphol. 1966; 16:381-

\section{0. | Article | PubMed}

24. Pittenger MF, Mackay AM, Beck SC, Jaiswal RK, Douglas R, Mosca JD, Moorman MA, Simonetti DW, Craig S and Marshak DR. Multilineage potential of adult human mesenchymal stem cells. Science. 1999; 284:143-7. | Article | PubMed

25. Fong CY, Richards M, Manasi N, Biswas A and Bongso A. Comparative growth behaviour and characterization of stem cells from human Wharton's jelly. Reprod Biomed Online. 2007; 15:708-18. | Article | PubMed

26. Zannettino AC, Paton S, Arthur A, Khor F, Itescu S, Gimble JM and Gronthos $S$. Multipotential human adipose-derived stromal stem cells exhibit a perivascular phenotype in vitro and in vivo. J Cell Physiol. 2008; 214:413-21. | Article | PubMed

27. Seo BM, Miura M, Gronthos S, Bartold PM, Batouli S, Brahim J, Young M, Robey PG, Wang CY and Shi S. Investigation of multipotent postnatal stem cells from human periodontal ligament. Lancet. 2004; 364:149-55. | Article | PubMed

28. Gronthos S, Mankani M, Brahim J, Robey PG and Shi S. Postnatal human dental pulp stem cells (DPSCs) in vitro and in vivo. Proc Natl Acad Sci U S A. 2000; 97:13625-30. | Article | PubMed Abstract | PubMed Full Text

29. Young HE, Steele TA, Bray RA, Hudson J, Floyd JA, Hawkins K, Thomas K, Austin T, Edwards C, Cuzzourt J, Duenzl M, Lucas PA and Black AC, $J$ r. Human reserve pluripotent mesenchymal stem cells are present in the connective tissues of skeletal muscle and dermis derived from fetal, adult, and geriatric donors. Anat Rec. 2001; 264:51-62. | Article | PubMed

30. Dominici M, Le Blanc K, Mueller I, Slaper-Cortenbach I, Marini F, Krause D, Deans R, Keating A, Prockop D and Horwitz E. Minimal criteria for defining multipotent mesenchymal stromal cells. The International Society for Cellular Therapy position statement. Cytotherapy. 2006; 8:315-7. | Article | PubMed

31. Menicanin D, Bartold PM, Zannettino AC and Gronthos S. Genomic profiling of mesenchymal stem cells. Stem Cell Rev. 2009; 5:36-50. Article | PubMed

32. Wagner W, Wein F, Seckinger A, Frankhauser M, Wirkner U, Krause U, Blake J, Schwager C, Eckstein V, Ansorge W and Ho AD. Comparative characteristics of mesenchymal stem cells from human bone marrow, adipose tissue, and umbilical cord blood. Exp Hematol. 2005; 33:140216. | Article | PubMed

33. Fong CY, Chak LL, Biswas A, Tan JH, Gauthaman K, Chan WK and Bongso A. Human Wharton's jelly stem cells have unique transcriptome profiles compared to human embryonic stem cells and other mesenchymal stem cells. Stem Cell Rev. 2011; 7:1-16. | Article | PubMed

34. Tsai MS, Hwang SM, Chen KD, Lee YS, Hsu LW, Chang YJ, Wang CN, Peng HH, Chang YL, Chao AS, Chang SD, Lee KD, Wang TH, Wang HS and Soong YK. Functional network analysis of the transcriptomes of mesenchymal stem cells derived from amniotic fluid, amniotic membrane, cord blood, and bone marrow. Stem Cells. 2007; 25:2511-23. | Article | PubMed

35. Adachi W, Ulanovsky H, Li Y, Norman B, Davis J and Piatigorsky J. Serial analysis of gene expression (SAGE) in the rat limbal and central corneal epithelium. Invest Ophthalmol Vis Sci. 2006; 47:3801-10. | Article | PubMed

36. Polisetti N, Agarwal P, Khan I, Kondaiah P, Sangwan VS and Vemuganti GK. Gene expression profile of epithelial cells and mesenchymal cells derived from limbal explant culture. Mol Vis. 2010; 16:1227-40. | Article | PubMed Abstract | PubMed Full Text

37. Diehn JJ, Diehn M, Marmor MF and Brown PO. Differential gene expression in anatomical compartments of the human eye. Genome Biol. 2005; 6:R74. | Article | PubMed Abstract | PubMed Full Text

38. Zhou M, Li XM and Lavker RM. Transcriptional profiling of enriched populations of stem cells versus transient amplifying cells. A comparison of limbal and corneal epithelial basal cells. J Biol Chem. 2006; 281:19600-9. | Article | PubMed

39. Ding Z, Dong J, Liu J and Deng SX. Preferential gene expression in the limbus of the vervet monkey. Mol Vis. 2008; 14:2031-41. | PubMed Abstract | PubMed Full Text 
Lim et al. Stem Cell Biology and Research 2014,

http://www.hoajonline.com/journals/pdf/2054-717X-1-1.pdf

40. Huang da W, Sherman BT and Lempicki RA. Systematic and integrative analysis of large gene lists using DAVID bioinformatics resources. Nat Protoc. 2009; 4:44-57. | Article | PubMed

41. Pfaffl MW, Horgan GW and Dempfle L. Relative expression software tool (REST) for group-wise comparison and statistical analysis of relative expression results in real-time PCR. Nucleic Acids Res. 2002; 30:e36. Article | PubMed Abstract | PubMed Full Text

42. Wan Safwani WK, Makpol S, Sathapan S and Chua KH. The changes of stemness biomarkers expression in human adipose-derived stem cells during long-term manipulation. Biotechnol Appl Biochem. 2011; 58:26170. | Article | PubMed

43. Mamidi MK, Pal R, Mori NA, Arumugam G, Thrichelvam ST, Noor PJ, Abdullah HM, Gupta PK, Das AK, Zakaria Z and Bhonde R. Co-culture of mesenchymal-like stromal cells derived from human foreskin permits long term propagation and differentiation of human embryonic stem cells. J Cell Biochem. 2011; 112:1353-63. | Article | PubMed

44. Schaffler A and Buchler C. Concise review: adipose tissue-derived stromal cells--basic and clinical implications for novel cell-based therapies. Stem Cells. 2007; 25:818-27. | Article I PubMed

45. Ranganath SH, Levy O, Inamdar MS and Karp JM. Harnessing the mesenchymal stem cell secretome for the treatment of cardiovascular disease. Cell Stem Cell. 2012; 10:244-58. | Article I PubMed Abstract | PubMed Full Text

46. Roobrouck VD, Vanuytsel $\mathrm{K}$ and Verfaillie CM. Concise review: culture mediated changes in fate and/or potency of stem cells. Stem Cells. 2011; 29:583-9. | Article | PubMed

47. Mathieu ME, Saucourt C, Mournetas V, Gauthereau X, Theze N, Praloran $\mathrm{V}$, Thiebaud $\mathrm{P}$ and Boeuf $\mathrm{H}$. LIF-dependent signaling: new pieces in the Lego. Stem Cell Rev. 2012; 8:1-15. | Article | PubMed Abstract | PubMed Full Text

48. Zunino R, Li Q, Rose SD, Romero-Benitez MM, Lejen T, Brandan NC and Trifaro JM. Expression of scinderin in megakaryoblastic leukemia cells induces differentiation, maturation, and apoptosis with release of plateletlike particles and inhibits proliferation and tumorigenesis. Blood. 2001; 98:2210-9. | Article | PubMed

49. Bork S, Horn P, Castoldi M, Hellwig I, Ho AD and Wagner W. Adipogenic differentiation of human mesenchymal stromal cells is down-regulated by microRNA-369-5p and up-regulated by microRNA-371. J Cell Physiol. 2011; 226:2226-34. | Article | PubMed

50. Peek R, Kammerer RA, Frank S, Otte-Holler I and Westphal JR. The angiopoietin-like factor cornea-derived transcript 6 is a putative morphogen for human cornea. J Biol Chem. 2002; 277:686-93. | Article | PubMed

51. Oshikawa M, Tsutsui C, Ikegami T, Fuchida Y, Matsubara M, Toyama S Usami R, Ohtoko $\mathrm{K}$ and Kato S. Full-length transcriptome analysis of human retina-derived cell lines ARPE-19 and Y79 using the vectorcapping method. Invest Ophthalmol Vis Sci. 2011; 52:6662-70. | Article | PubMed

52. Feinstein $Y$ and Klar A. The neuronal class 2 TSR proteins F-spondin and Mindin: a small family with divergent biological activities. Int J Biochem Cell Biol. 2004; 36:975-80. | Article | PubMed

53. Lawrence HJ, Sauvageau G, Humphries RK and Largman C. The role of HOX homeobox genes in normal and leukemic hematopoiesis. Stem Cells. 1996; 14:281-91. | Article | PubMed

54. Nusse R. Wnt signaling and stem cell control. Cell Res. 2008; 18:523-7. | Article | PubMed

55. Nakatsu MN, Ding Z, Ng MY, Truong TT, Yu F and Deng SX. Wnt/betacatenin signaling regulates proliferation of human cornea epithelial stem/progenitor cells. Invest Ophthalmol Vis Sci. 2011; 52:4734-41. | Article | PubMed Abstract | PubMed Full Text

56. Mukhopadhyay M, Gorivodsky M, Shtrom S, Grinberg A, Niehrs C Morasso $\mathrm{Ml}$ and Westphal $\mathrm{H}$. Dkk2 plays an essential role in the corneal fate of the ocular surface epithelium. Development. 2006; 133:2149-54. | Article | PubMed

57. Saxena $A$ and Carninci P. Long non-coding RNA modifies chromatin: epigenetic silencing by long non-coding RNAs. Bioessays. 2011; 33:830-
9. | Article | PubMed Abstract | PubMed Full Text

58. Guttman M, Donaghey J, Carey BW, Garber M and Grenier JK. lincRNAs act in the circuitry controlling pluripotency and differentiation. Nature. 2011; 477:295-300. | Article | PubMed Abstract | PubMed Full Text

\section{Citation:}

Lim MN, Hussin NH, Othman A, Umapathy T, Gurbind S, Baharuddin P, Jamal R and Zakaria Z. Comparative global gene expression profile of human limbal stromal cells, bone marrow mesenchymal stromal cells, adipose-derived mesenchymal stromal cells and foreskin fibroblasts. Stem Cell Biol Res. 2014; 1:1. http://dx.doi.org/10.7243/2054-717X-1-1 